\title{
A TWO YEAR HOSPITAL BASED PROSPECTIVE STUDY OF SICKLE CELL DISORDERS IN CHILDREN AND COMPARISON WITH OTHER HOSPITAL BASED REGIONAL STUDIES IN INDIA
}

\author{
Sunil Kumar Komanapalli¹, Siva Ranjan D², Vijaya Bhaskar P33, Krishna L4
}

\section{HOW TO CITE THIS ARTICLE:}

Sunil Kumar Komanapalli, Siva Ranjan D, Vijaya Bhaskar P, Krishna L. "A two year hospital based prospective study of Sickle Cell Disorders in children and comparison with other hospital based Regional Studies in India". Journal of Evolution of Medical and Dental Sciences 2014; Vol. 3, Issue 03, January 20; Page: 649-656, DOI:10.14260/jemds/2014/1880

ABSTRACT:: Various haemoglobinopathies are major health problem in east godavari district, andhra pradesh. Because of high prevalence of these disorders, we undertook limited hospital based study. AIMS: To study and to evaluate the sickle cell disorders in children who attended outpatient pediatric department, GGH, Kakinada METHODS AND MATERIAL: The present prospective study included 82 patients, referred for screening of hemoglobin disorders from October 2010 to September 2012, with Clinical history of anaemia, jaundice, splenomegaly and fever. Blood samples were collected into EDTA for testing parameters like hemogram, peripheral smear, reticulocyte count, $\mathrm{Hb}$ F(fetal hemoglobin) study, osmotic fragility test, $\mathrm{Hb} \mathrm{H}$ Inclusion Bodies, hemoglobin analysis by HPLC (high performance liquid chromatography) and urine was collected for urobilinogen test. RESULTS: Total numbers of sickle cell disease and trait were 31 out of 82 screened cases with male predominance and six cases were sickle heterozygous conditions. The prevalence of sickle cell disorders is $37 \%$. 54\% of sickle cell cases were associated with iron deficiency anemia. Serum bilirubin levels are increased more in sickle cell disease compared to other abnormal Hb disorders. CONCLUSIONS: Our study indicates that sickle cell disease and trait were most common haemoglobinopathies. 93\% of sickle cell cases had presented with Microcytic hypochromic anemia. The prevalence of sickle cell disease is $37 \%$, although the present study is Hospital based which cannot represent any community or population, but it emphasizes the need of knowing the magnitude of this problem in this region.

KEY-WORDS: Sickle cell disease, Haemoglobinopathies, Prevalence, HPLC, Hospital based study.

INTRODUCTION: Sickle cell disease is a common hereditary hemoglobinopathy. It is caused by substitution of valine for glutamic acid in position six of beta globin chain. There are two main forms of Sickle cell disease. The homozygous state or sickle cell anemia ( $\beta$ genotype SS) and Sickle cell trait ( $\beta$ genotype AS), the heterozygous state. ${ }^{1}$ In 1910, James Herrick, examined a 20 year old anemic patient with cough and fever, and stated that the RBC were only half of their normal number and were thin, elongated with crescent and sickle shape ${ }^{1}$.

In India, it was reported by Lehmann and Cutbush in the aborigines at Nilgiri hills in $1952^{2}$. Dunlop and Mozumdar in 1952 identified the gene in Assam in the tea garden workers, who had migrated from Orissa ${ }^{3}$. Reports of the gene in Uttar Pradesh (Bhatia.et.al.1955), west India (sukumaranet.al.1956) ${ }^{4}$, central India (Shukla \& Solanki 1958)5, West Bengal (Choudury, Ghosh, Mukherjee 1964)6, and Andhra Pradesh were put forth later. In India, Hb S is mainly present in tribal and non-caste communities, with carrier prevalence of up to $40 \% .^{7}$ Extensive field studies in all the taluqs of East Godavari District, parts of Adilabad, Visakhapatnam, Warangal and the entire tribal 
belt in West Godavari District from 1978 to date, revealed Hb S, Rampa, Koyadora, Hofu and a new alpha chain variant, Hb Godavari [ $\alpha 95$ (G2) pro $\square$ Thre] and also $\beta$ thalassemia and $\alpha$ thalassemia interacting with $\mathrm{HbS} .{ }^{8}$

The present prospective study included 82 patients; study was done on Children up to 18 years of age with Clinical history of anaemia, jaundice, splenomegaly and fever. Haemoglobinopathies are a part of abnormal hemoglobin's and recognized as a global problem. The most common is sickle cell disease, worldwide in distribution, causing severe disease and death in children and adolescence. The aim of this study was to know the prevalence and to evaluate the sickle cell disorders. As these disorders are common in Andhra Pradesh and it was conducted among children attended the Pediatric outpatient department (OPD) at Government General Hospital, Kakinada.

MATERIALS AND METHODS: The present prospective study included 82 patients, referred for screening of hemoglobin disorders from October 2010 to September 2012 from pediatric department, GGH-RMC, Kakinada. Children selected are of age group up to 18 years. Clinical history and physical findings were recorded as provided by the referring physician. We also examined clinically with special attention to anemia, splenomegaly and other relevant features noted.

Blood samples were collected into EDTA loaded bottles, for testing parameters like hemogram, peripheral smear, reticulocyte count, $\mathrm{Hb}$ F(fetal hemoglobin) study, osmotic fragility test, $\mathrm{Hb} \mathrm{H}$ Inclusion Bodies, hemoglobin analysis by HPLC and urine was collected for urobilinogen test. Biochemical parameters like serum total bilirubin, serum ferritin values were also noted.

RESULTS: Fifty one (62\%) patients out of 82 studied had hemoglobinopathy and 31 (38\%) had Iron deficiency anemia (IDA). Among 51 patients who had disorders of abnormal $\mathrm{Hb}$ synthesis was described in [table 1].

\begin{tabular}{|l|c|}
\hline \multicolumn{1}{|c|}{ Cases } & Total \\
\hline Sickle cell disease & $19(37 \%)$ \\
\hline Sickle cell trait & $12(23 \%)$ \\
\hline Sickle- thalassemia & $4(8 \%)$ \\
\hline $\begin{array}{l}\text { Sickle - hereditary persistence } \\
\text { of fetal hemoglobin (HPFH) }\end{array}$ & $2(4 \%)$ \\
\hline Other Hb disorders & $14(27 \%)$ \\
\hline Table 1: Disorders of abnormal Hb synthesis $(\mathrm{n}=51)$
\end{tabular}

An age and sex distribution of Sickle cell disease (n-19) and trait (n-12) were showed male preponderance [figure 1].

Among 19 patients of sickle cell disease 17 had moderate to severe anemia and only two cases had mild anemia. Hb\%, serum bilirubin and HPLC profiles of Sickle cell disease were showed in [table 2]. 


\begin{tabular}{|c|c|c|c|}
\hline Cases & Hb gm.\% & $\begin{array}{c}\text { Unconjugated } \\
\text { Serum Bilirubin }(\mathrm{mg} / \mathrm{dl})\end{array}$ & HPLC \% \\
\hline $117 / 11$ & 5 & 14.5 & Hb S: 72 Hb A: 4.6 \\
\hline $866 / 11$ & 4.8 & 13.5 & $\mathrm{Hb} \mathrm{S:} 82.3 \mathrm{Hb} \mathrm{A}: 6.7$ \\
\hline $1399 / 11$ & 5.2 & 8.8 & $\mathrm{Hb} \mathrm{S:} 81.9 \mathrm{Hb} \mathrm{A:} 0$ \\
\hline $282 / 12$ & 6.2 & 6.8 & Hb S: 57.2 Hb A: 32.4 \\
\hline $127 / 12$ & 2.8 & 11.5 & Hb S: 72.9 Hb A: 7.5 \\
\hline $151 / 12$ & 5.3 & 3.5 & Hb S: 77.3 Hb A: 3.1 \\
\hline $520 / 12$ & 5.6 & 14.8 & Hb S: 63.3 Hb A: 15.7 \\
\hline $356 / 11$ & 9.2 & 8.5 & Hb S: 69.8 Hb A: 4.9 \\
\hline $1032 / 11$ & 10.5 & 10 & $\mathrm{Hb} \mathrm{S:} 78.3 \mathrm{Hb}$ A: 6.0 \\
\hline $1033 / 11$ & 9.8 & 3.3 & $\mathrm{Hb} \mathrm{S:} 79.7 \mathrm{Hb} \mathrm{A:} 4.8$ \\
\hline $1631 / 11$ & 8.2 & 9.5 & $\mathrm{Hb} \mathrm{S:} 79.5 \mathrm{Hb} \mathrm{A:} 4.4$ \\
\hline $1913 / 11$ & 10 & 8.5 & Hb S: 79.4 Hb A: 1.8 \\
\hline $1940 / 11$ & 8.5 & 9.2 & $\mathrm{Hb} \mathrm{S:} 83 \mathrm{Hb} \mathrm{A:} 1.6$ \\
\hline $342 / 12$ & 7.8 & 5.8 & $\mathrm{Hb} \mathrm{S:} 75.7 \mathrm{Hb} \mathrm{A:} 0$ \\
\hline $446 / 12$ & 8 & 10.5 & $\mathrm{Hb} \mathrm{S:} 69 \mathrm{H} \mathrm{b} \mathrm{A:} 10$ \\
\hline $945 / 12$ & 9 & 2.8 & Hb S: $72.1 \mathrm{Hb}$ A: 4.5 \\
\hline $948 / 12$ & 6.8 & 6.2 & $\mathrm{Hb} \mathrm{S:} 74.3 \mathrm{Hb} \mathrm{A:} 4.5$ \\
\hline $990 / 12$ & 7.5 & 3.6 & Hb S: 71.8 Hb A: 0.9 \\
\hline $996 / 12$ & 9.5 & 3 & $\mathrm{Hb} \mathrm{S:} 54.7 \mathrm{Hb} \mathrm{A:} 21$ \\
\hline
\end{tabular}

All the 12 cases showed moderate to severe anemia in sickle cell trait. $\mathrm{Hb} \%$, serum bilirubin and HPLC profiles of Sickle cell trait were showed in [table 3].

\begin{tabular}{|c|c|c|c|}
\hline Cases & Hb gm.\% & $\begin{array}{c}\text { Unconjugated } \\
\text { Serum Bilirubin (mg/d) }\end{array}$ & HPLC \% \\
\hline $1126 / 10$ & $\mathbf{3 . 1}$ & 4.4 & Hb S: 12.25 Hb A:86.4 \\
\hline $1707 / 10$ & $\mathbf{3 . 9}$ & 3.2 & Hb S:22.5 Hb A: 68.0 \\
\hline $423 / 11$ & $\mathbf{7 . 1}$ & 2.2 & Hb S: 27.9 Hb A: 64.5 \\
\hline $803 / 12$ & $\mathbf{6 . 5}$ & 3.2 & Hb S: 34.1 Hb A: 61.2 \\
\hline $1175 / 11$ & $\mathbf{2 . 1}$ & 2.8 & Hb S: 16.25 Hb A:78.8 \\
\hline $1254 / 11$ & $\mathbf{5 . 5}$ & 2.2 & Hb S: 12.3 Hb A: 79 \\
\hline $1790 / 11$ & $\mathbf{5 . 8}$ & 4.1 & Hb S: 11.1 Hb A: 83.7 \\
\hline $1832 / 11$ & $\mathbf{5}$ & 2.0 & Hb S: 14.6 Hb A: 83 \\
\hline $1860 / 11$ & $\mathbf{4 . 5}$ & 2.1 & Hb S: 5.33 H b A: 91.5 \\
\hline $1861 / 11$ & $\mathbf{6}$ & 2.9 & Hb S: 40 Hb A: 56.7 \\
\hline $705 / 12$ & $\mathbf{9}$ & 2.6 & Hb S: 22.2 Hb A: 58.5 \\
\hline $331 / 11$ & $\mathbf{9 . 1}$ & 5 & Hb S: 15.5 Hb A: 82.9 \\
\hline \multicolumn{2}{|r|}{ Table 3: Hb\%, serum bilirubin and HPLC profiles of Sickle cell trait }
\end{tabular}

Table 3: Hb\%, serum bilirubin and HPLC profiles of Sickle cell trait 
$\mathrm{Hb} \%, \mathrm{MCV}$, serum bilirubin and HPLC profiles of Sickle- $\beta$ thalassemia cases was showed in [table 4].

\begin{tabular}{|c|c|c|c|c|}
\hline Cases & Hb gm.\% & $\operatorname{MCV}$ in(fl) & $\begin{array}{c}\text { Unconjugated } \\
\text { Serum Bilirubin(mg/dl) }\end{array}$ & HPLC \\
\hline $463 / 11$ & 8.3 & 87 & 4.4 & $\begin{array}{l}\text { Hb S: } 65.3 \% \\
\text { Hb F: } 25.8 \% \\
\text { Hb A: } 3.9 \% \\
\text { HbA2: } 4.9 \%\end{array}$ \\
\hline $1335 / 11$ & 6.5 & 69 & 4.3 & $\begin{array}{l}\text { Hb S: } 70.2 \% \\
\text { Hb F: } 5.2 \% \\
\text { Hb A: } 16.2 \% \\
\text { Hb A2: } 6.1 \%\end{array}$ \\
\hline $172 / 12$ & 7 & 58 & 4.8 & $\begin{array}{l}\text { Hb S: } 60.6 \% \\
\text { Hb F: } 24.5 \% \\
\text { Hb A: } 9.1 \% \\
\text { HbA2: } 4.6 \%\end{array}$ \\
\hline $180 / 12$ & 9.2 & 76 & 2.1 & $\begin{array}{l}\text { Hb A: } 41 \% \\
\text { Hb F: } 28.4 \% \\
\text { Hb S: } 28 \% \\
\text { HbA2: } 3.7 \%\end{array}$ \\
\hline
\end{tabular}

Table 4: Hb\%, MCV, serum bilirubin and HPLC profiles of Sickle- $\beta$ thalassemia cases

Two Sickle-HPFH cases showed mild anemia, Hb, MCV and unconjugated serum bilirubin values and HPLC profile was showed in [table 5].

\begin{tabular}{|c|c|c|c|c|}
\hline Cases & Hb\% & MCV(fl) & $\begin{array}{c}\text { Unconjugated } \\
\text { Serum. bilirubin(mg/dl) }\end{array}$ & HPLC \% \\
\hline $1830 / 11$ & 10.1 & 77 & 1.5 & $\begin{array}{l}\text { Hb S: } 4.25 \% \\
\text { Hb A: } 5.86 \% \\
\text { Hb F: } 7.97 \% \\
\text { Hb A2: } 1.91 \%\end{array}$ \\
\hline $1978 / 11$ & 10.9 & 82 & & $\begin{array}{l}\text { Hb S: } 26.09 \% \\
\text { Hb F: } 29.54 \% \\
\end{array}$ \\
& & & & $\begin{array}{l}\text { Hb A: } 43.01 \% \\
\text { HbA2: } 1.34 \%\end{array}$ \\
\hline
\end{tabular}

Table 5: Hb, MCV and unconjugated serum bilirubin values and HPLC profile

DISCUSSION: The cumulative gene frequency of haemoglobinopathies in India is $4.2 \%{ }^{9}$. $\mathrm{Hb} \mathrm{S}$ has been reported from various Indian states, community and ethnic groups with an average frequency of $4.3 \%$ (range $0-44 \%$ ). ${ }^{10}$ The present study was mainly hospital based case study, which cannot be 
regarded as representative of any community or population. The study showed high prevalence of sickle cell disorders with male preponderance in concordance with the other hospital based regional studies. It was showed in [table 6].

\begin{tabular}{|l|c|}
\hline \multicolumn{1}{|c|}{ Region } & Prevalence \\
\hline Western Maharashtra $^{11}$ & $15.8 \%$ \\
\hline Orissa $^{12}$ & $16.5 \%$ \\
\hline Uttar Pradesh $13^{13}$ Present study & $3.2 \%$ \\
\hline \multicolumn{2}{|c|}{ Pr \% } \\
\hline
\end{tabular}

\section{Table 6: Prevalence of sickle cell disorders}

Most of the sickle cell disease patients presented with fever, yellowish discoloration of eyes and few presented with splenomegaly and chest pain. Sickling with $2 \%$ sodium metabisulfite appeared after one hour in most of the cases and after six hours in a few cases. In all the cases, reticulocyte count and urobilinogen was increased and osmotic fragility was decreased. Seven (7/19) patients were above the age of 10 years, although they were symptomatic from childhood, indicating lack of awareness about the disease or tendency of the parents to seek advice of the doctors only as last resort. These cases had no splenomegaly, attributed to autosplenectomy. Four (4/19) patients were born of consanguineous marriage.

Out of 12 Sickle cell trait cases, most of them presented with fever and dyspnea. Sickling was positive in five (5/12) cases and negative in seven (7/12) cases, reason being low $\mathrm{Hb} S$ values (less than $20 \%$ in HPLC). Sickling test (sodium metabisulphite) is less sensitive in detecting these cases. Reticulocyte count and serum bilirubin are increased in only two (2/12) cases. Urobilinogen is increased in only one case. Three patients are born of consanguineous marriage.

Seventeen cases of sickle cell disease and all the cases of sickle cell trait had microcytic hypochromic (MCHC) anemia, in contrast to usual normocytic normochromic blood picture. These cases had low serum Iron \& Ferritin values, indicating associated iron deficiency or alpha thalassemia trait. High incidence of IDA has been reported in patients with sickle cell disease from India ${ }^{14}$. Alpha thalassemia trait should be suspected with sickle cell disease or trait when $\mathrm{Hb} \mathrm{F}$ is unusually low with typical blood indices and low Hb S.15-17 In present study 54\% sickle cases were associated with MCHC anemia correlated with Gujarat study [table 7]

\begin{tabular}{|c|c|}
\hline Studies & MCHC anemia in sickle cases \\
\hline Gujarat $^{18}$ & $70 \%(24 / 34)$ \\
\hline South Orissa ${ }^{11}$ & $96.5 \%(272 / 282)$ \\
\hline Present study & $54 \%(17 / 31)$ \\
\hline \multicolumn{2}{|c|}{ Table 7: Comparison of Sickle cases associated with } \\
microcytic hypochromic anemia with other regional studies
\end{tabular}


When compared to sickle cell disease, thalassemia major cases had lower values of serum bilirubin, indicating that lysis of precursor cells liberates less bilirubin compared to that seen with lysis of mature erythrocytes as in sickle cases [table 8].

\begin{tabular}{|c|c|}
\hline Cases & $\begin{array}{c}\text { Unconjugated bilirubin } \\
\text { average(mg/dl) }\end{array}$ \\
\hline Sickle cases & $8(3.5-14.5)$ \\
\hline Thalassemia major & $3.4(2.1-4.8)$ \\
\hline Double heterozygous conditions & $3.5(2.1-5.4)$ \\
\hline $\begin{array}{c}\text { Table 8: Comparison of serum bilirubin values of } \\
\text { sickle cell cases with other Haemoglobinopathies }\end{array}$ \\
\hline
\end{tabular}

Among four patients of sickle thalassemia, two were born of consanguineous marriage. Average age of presentation was 5 years. They presented with fever, recurrent respiratory tract infections. On examination they had mild to moderate splenomegaly. Hemogram revealed moderate anemia. In all these cases serum ferritin values were increased.

Sickle -HPFH cases presented with mild anemia, this can be due to high $\mathrm{Hb} F$ value protecting form sickling. Acid elution test revealed pan cellular distribution of $\mathrm{Hb} \mathrm{F}$.

\section{CONCLUSION:}

1. Total number of abnormal $\mathrm{Hb}$ disorders is 51 out of 82 screened cases with male predominance. Most of the patients belonged to the age group of 1-4 yrs. in sickle cell trait and 5-9 yrs. in sickle cell disease.

2. Fifty four percent of sickle cell cases are associated with iron deficiency anemia. Serum bilirubin levels are increased more in sickle cell disease compared to other abnormal $\mathrm{Hb}$ disorders.

3. Our study is a Hospital based study which cannot represent any community or population, but it emphasizes the need of knowing the magnitude of this problem in this region

4. Unlike many other genetic disorders where couple at risk cannot be easily diagnosed, sickle and abnormal hemoglobin give a tremendous opportunity for effective control of birth. There has to be only a political will to implement and achieve this.

5. Adequate measures and screening procedures should be adopted to reduce sickle cell disorders. Screening is affordable way to detect carriers and can be done in different societies like in high school, before marriage or in antenatal clinics.

\section{REFERENCES:}

1. Herrick JB. Peculiar elongated and sickle shaped red blood corpuscles in a case of severe anaemia. 1910. Yale J Biol Med. 2001; 74(3): 179-84.

2. Lehman H.and Marie Cutbush. Sickle cell trait in southern India. Br Med J. 1952; 1: 404-5. 
3. Dunlop and Mozumdar UK: The occurrence of Sickle cell anemia among a group of tea garden labourers in upper Assam. Indian Med Gaz.1952;87:387-91

4. Sukumaran PK., Sanghavi LD., Vyas GN: Sickle cell trait in some tribes of Western India. Current Sci. 1956; 25:290.

5. Shukla RS, Solanki BR. Sickle cell trait in Central India. Lancet 1958; 1:297-8.

6. Choudary S., Ghosh J, Mukherjee B: Study of Blood groups and Hemoglobin variants among the Santral tribe in Midnapore District of West Bengal, India. Am J Phys Anthrop. 1967; 26:307-12.

7. Mohanty D, Colah R B, Gorakshakar A C, Nadkarni A H, Phanasgaonkar S P, Shetty S et al. Genetic disorders in haematological practice in India. Community Genti. 2002;5 (3): 197 -200.

8. Wajcman H, Kister J, Riou J, Galacteros F, Girot R, Maier-Redelsperger M, Nayudu NV, Giordano PC: Hb Godavari [alpha 95(G2)Pro—-Thr]: a neutral amino acid substitution in the alpha 1 beta 2 interface that modifies the electrophoretic mobility of hemoglobin. Hemoglobin. 1998 Jan;22(1):11-22.

9. Sarnaik SA. Thalassaemia and related haemoglobinopathies. Indian J Pediatr 2005;72:319-24.

10. Mohanty D, Mukherjee MB. Sickle cell disease in India. Curr Opin Hematol 2002;9:117-22.

11. Ambekar SS, M.A. Phadke, G.D. Mokashi, M.P. Bankar, V.A. Khedkar, V. Venkat D.G. Basutkar Pattern of Haemoglobinopathies in western maharastra, Indian Paediatrics 2001; 38: 530-534.

12. Balgir RS. Spectrum of haemoglobinopathies in the state of Orissa, India: a ten year cohort study. J Assoc Physicians India 2005; 53: 1021-1026.

13. Vineeta G, Jyoti Shukla, Vijai Tilak, Baldev Bhatia. Spectrum of Haemoglobinopathies in Eastern Uttar Pradesh. Indian J of Pedia. 2009;76: 857.

14. Balgir RS. The burden of haemoglobinopathies in India and the challenges ahead. Curr Sci: 2000; 79:1536-1547.

15. WHO- executive board EB118/5, 118th Session Report by the Secretariat on Thalassaemia and other haemoglobinopathies: Prevalence of Haemoglobinopathies. 11 May 2006; p.1-8.

16. Varawalla NY, Old JM, Sarkar R, Venkatean R, Weatherall DJ. The spectrum of beta thalassaemia mutations on the Indian subcontinent; the basis of prenatal diagnosis. Br J Haematol 1991;78:242-247.

17. Das BM, Deka R, Das R. Haemoglobin E in six populations of Assam. Ind J Anthrop Assoc 1980;15:153-156.

18. Patel Ashwin P, Naik Madhuben R, Shah Nilam M, Sharma Narmadeshwar P, Parmar Prakash H. Prevalence of Common Haemoglobinopathies in Gujarat: An analysis of large population screening programme. National Journal of Community Medicine, 2012;3(1):112-6. 


\section{ORIGINAL ARTICLE}

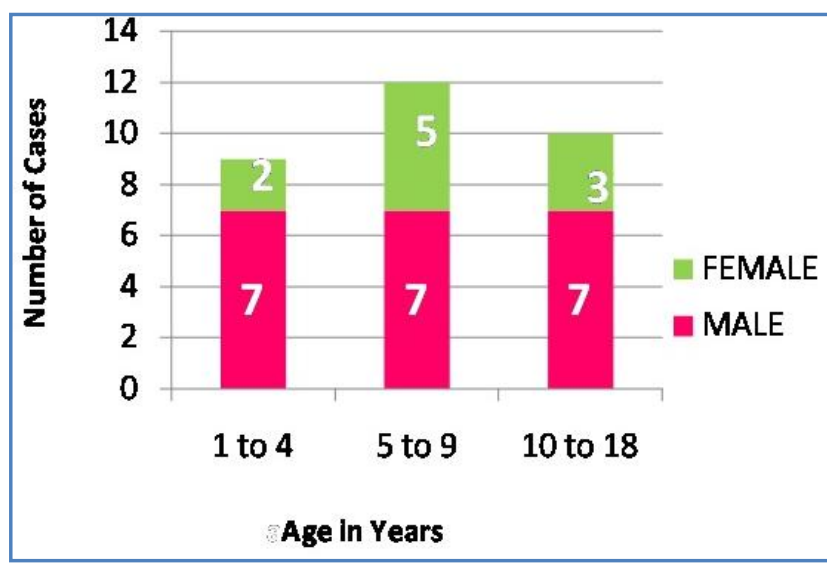

Fig. 1: Age and sex distribution of

Sickle cell disease and trait

\section{AUTHORS:}

1. Sunil Kumar Komanapalli

2. Siva Ranjan D.

3. Vijaya Bhaskar P.

4. Krishna L.

\section{PARTICULARS OF CONTRIBUTORS:}

1. Assistant Professor, Department of Pathology, Konaseema Institute of Medical Sciences and Research Foundation, Amalapuram.

2. Assistant Professor, Department of Pathology, Konaseema Institute of Medical Sciences and Research Foundation, Amalapuram.

3. Associate Professor, Department of Pathology, RMC, Kakinada.
4. Professor and HOD, Department of Pathology, RMC, Kakinada.

\section{NAME ADDRESS EMAIL ID OF THE CORRESPONDING AUTHOR:}

Dr. Siva Ranjan D,

H.No.: C-108, Phase 2,

Hill Colony, Vanasthalipuram,

Hyderabad - 500070.

Email - avis.reddy@gmail.com

Date of Submission: 30/12/2013.

Date of Peer Review: 31/12/2013.

Date of Acceptance: 07/01/2014.

Date of Publishing: 16/01/2014. 